\title{
Body Fat Percentiles for German Children and Adolescents
}

\author{
Sandra Plachta-Danielzik ${ }^{a}$ Marie Isabel Gehrke ${ }^{a}$ Britta Kehden ${ }^{a}$ \\ Katrin Kromeyer-Hauschild ${ }^{b}$ Monika Grillenberger ${ }^{c}$ Corinna Willhöft ${ }^{c}$ \\ Anja Bosy-Westphala Manfred J. Müller ${ }^{a}$ \\ ${ }^{a}$ Institute of Human Nutrition and Food Science, Christian-Albrechts University, Kiel, \\ bInstitute of Human Genetics, University Hospital, Friedrich Schiller-University Jena, Jena, \\ ${ }^{c}$ Federal Research Institute for Nutrition and Food, Max Rubner Institute (MRI), Karlsruhe, \\ Germany
}

\section{Key Words}

Fat mass $\cdot$ Percentiles $\cdot$ Children $\cdot$ Adolescents

\begin{abstract}
Objective: The aim of this study was to define body fat percentiles for German children and adolescents aged 3-16 years using the largest German database. Methods: The study population included 11,632 girls and 11,604 boys. Data were pooled from: i) Kiel Obesity Prevention Study (KOPS), acquisition period: 1996-2008, $\mathrm{n}=12,237$; ii) 'Better diet. More exercise. KINDERLEICHT-REGIONS', acquisition period: 2007, $n=9,405$; and iii) examination of Jena schoolchildren, acquisition period: $2005, n=1,594$. Body fat mass was measured by bioelectrical impedance analysis using a population-specific algorithm. Data were weighted to achieve a representative sample for Germany. Percentile curves were constructed by the LMS method and proved by Worm plots and Q-statistic. Results: In both genders, the higher body fat percentile curves sloped downwards to age 7 years, whereas the lower percentiles declined up to 8.5 years. Thereafter fat mass remained nearly constant with age in boys and increased in girls. The 10th percentile achieved a minimum of $10-11 \%$ body fat in both genders, whereas the 90th percentile curve fluctuated between 29 and $44 \%$ in boys or $30-43 \%$ in girls. The association between fat mass and blood pressure was too weak to define disease-related cut-offs. Conclusion: These body fat percentiles are suitable reference values for German children and adolescents.
\end{abstract}

Copyright (c) 2012 S. Karger GmbH, Freiburg

\section{Introduction}

BMI is widely used to define overweight in children and adolescents, but BMI is a proxy measure of adiposity only. Waist circumference (WC), skinfold thicknesses and body fat mass have been used to characterize adiposity. Fat mass can be calculated from field methods like skinfold thicknesses and bioelectrical impedance analysis (BIA) measurements [1-3] or more 
advanced technologies like dual energy X-ray absorptiometry (DXA). The latter technique is not allowed for use in children in Europe. Up to now, fat mass percentiles for children have been published which were based on skinfold measurements in Spain [4], on a combination of BIA and anthropometry in the USA [5], and on dual energy X-ray absorptiometry measurements also in the USA [6]. For the USA [7], the UK [8], Poland [9], Hong Kong [10], Greece [11], and Turkey [12] fat mass percentiles derived from BIA measurements have been published recently. However, due to the different devices and protocols, a direct comparison of these fat masses is not possible. BIA values differ between different BIA devices and algorithms used $[8,10,11]$. In addition, percentiles should be based on large cohorts with sufficient number of subjects in every age group, ideally representative. These criteria are not given for the so far published fat mass percentiles (except for data from Hong Kong, but this population is not comparable to European children). The numbers of subjects investigated in European fat mass percentile populations ranged from 193 to 4,076 children and adolescents [8, 9, 11, 12], and even the US reference percentiles derived from NHANES III included 757 children only [7]. Thus, there is a need for fat mass percentiles based on a powerful study population.

Another problem using fat mass percentiles concerns the cut-off to define overfat. In adults, cut-offs to define overweight are based on a fixed BMI value of 25 which is again related to disease risk [13]. Today, the 85th and 90th percentiles are used to define childhood overweight in the USA and Europe. These cut-offs are not directly related to disease risk but showed a relation between childhood obesity and incidence of metabolic disorders in young adulthood [14].

For this study, data from three epidemiological German studies on fat mass derived from BIA measurements using the same BIA devices, the same study conditions, and a unique population-specific algorithm were pooled to obtain the currently largest database for Germany. The aim of this study was to define representative body fat percentiles based on BIA measurements for German children and adolescents aged 3-16 years. In addition, we have tried to define cut-offs of overfat according to disease-related risk in children and adolescents.

\section{Participants and Methods}

\section{Study Design}

The study population is based on three German cohorts including data of 27,024 children and adolescents (13,432 girls and 13,592 boys) aged 2-18 years. Data were collected as part of the Kiel Obesity Prevention Study (KOPS), the project 'Better diet. More exercise. KINDERLEICHT-REGIONS', and the examination of Jena schoolchildren. KOPS intends to characterize the determinants of childhood overweight and the effect of preventive measures within schools as well as within families in Northwest Germany. Details of the study design and recruitment procedure have been described elsewhere [15, 16]. 'Better diet. More exercise. KINDERLEICHT-REGIONS' is a project initiated by the German Federal Ministry of Food, Agriculture, and Consumer Protection. Between the end of 2006 and 2009, 24 nationwide pilot projects developed and carried out strategies for prevention of overweight for children up to age of 10 years. Their effectiveness is evaluated by the Max Rubner Institute (MRI) in Karlsruhe, Germany. In $2005 / 2006$ the cross-sectional survey of Jena schoolchildren was conducted to describe the prevalence and determinants of overweight and obesity among schoolchildren in Jena [17]. The characteristics of the 3 studies are given in table 1 . When compared with the first two cohorts, the Jena cohort showed a lower prevalence of overweight.

\section{Study Population}

From the total study population 1,257 subjects were excluded due to invalid BIA measurements (exclusion criteria are given below). In addition, we excluded 239 participants below 3 years and above 16 years because of very small numbers in these age groups. To achieve a representative sample for Germany, 
Table 1. Characteristics of the reference population 1 (adapted to KiGGS) stratified to the single studies

\begin{tabular}{|c|c|c|c|c|c|c|}
\hline & \multicolumn{2}{|l|}{ KOPSa } & \multicolumn{2}{|c|}{ KINDERLEICHT-REGIONSb } & \multicolumn{2}{|l|}{ Jenac $^{c}$} \\
\hline & boys & girls & boys & girls & boys & girls \\
\hline Acquisition period & 1996-2008 & & 2007 & & 2005 & \\
\hline Sample size & 5,940 & 6,297 & 4,832 & 4,573 & 832 & 762 \\
\hline $\begin{array}{l}\text { Median age, years } \\
\text { (IQR) }\end{array}$ & $\begin{array}{l}9.76 \\
(6.41-13.70)\end{array}$ & $\begin{array}{l}9.84 \\
(6.42-14.08)\end{array}$ & $\begin{array}{l}7.17 \\
(5.25-7.92)\end{array}$ & $\begin{array}{l}7.17 \\
(5.33-7.83)\end{array}$ & $\begin{array}{l}6.04 \\
(4.77-9.24)\end{array}$ & $\begin{array}{l}5.98 \\
(4.76-9.22)\end{array}$ \\
\hline $\begin{array}{l}\text { Median height, } m \\
\text { (IQR) }\end{array}$ & $\begin{array}{l}1.40 \\
(1.22-1.58)\end{array}$ & $\begin{array}{l}1.40 \\
(1.22-1.60)\end{array}$ & $\begin{array}{l}1.25 \\
(1.13-1.31)\end{array}$ & $\begin{array}{l}1.23 \\
(1.13-1.30)\end{array}$ & $\begin{array}{l}1.21 \\
(1.09-1.39)\end{array}$ & $\begin{array}{l}1.19 \\
(1.09-1.38)\end{array}$ \\
\hline $\begin{array}{l}\text { Median weight, kg } \\
\text { (IQR) }\end{array}$ & $\begin{array}{l}32.6 \\
(23.5-49.7)\end{array}$ & $\begin{array}{l}33.8 \\
(24.0-50.9)\end{array}$ & $\begin{array}{l}24.6 \\
(19.9-28.9)\end{array}$ & $\begin{array}{l}23,9 \\
(19,7-28,1)\end{array}$ & $\begin{array}{l}23.0 \\
(18.2-31.5)\end{array}$ & $\begin{array}{l}23.0 \\
(18.3-31.5)\end{array}$ \\
\hline $\begin{array}{l}\text { Median BMI, kg/m² } \\
\text { (IQR) }\end{array}$ & $\begin{array}{l}17.0 \\
(15.4-19.8)\end{array}$ & $\begin{array}{l}17.5 \\
(15.6-20.3)\end{array}$ & $\begin{array}{l}16.0 \\
(15.0-17.3)\end{array}$ & $\begin{array}{l}15.9 \\
(14.9-17.3)\end{array}$ & $\begin{array}{l}15.9 \\
(15.0-17.0)\end{array}$ & $\begin{array}{l}16.0 \\
(14.9-17.3)\end{array}$ \\
\hline $\begin{array}{l}\text { Median BMI-SDS } \\
\text { (IQR) }\end{array}$ & $\begin{array}{l}0.10 \\
(-0.51 \text { to } 0.81)\end{array}$ & $\begin{array}{l}0.16 \\
(-0.46 \text { to } 0.83)\end{array}$ & $\begin{array}{l}0.12 \\
(-0.46 \text { to } 0.82)\end{array}$ & $\begin{array}{l}0.13 \\
(-0.47 \text { to } 0.78)\end{array}$ & $\begin{array}{l}-0.03 \\
(-0.59 \text { to } 0.54)\end{array}$ & $\begin{array}{l}0.02 \\
(-0.60 \text { to } 0.62)\end{array}$ \\
\hline Overweight, \% & 9.1 & 9.2 & 7.6 & 6.9 & 5.9 & 6.0 \\
\hline Obesity, \% & 5.6 & 5.2 & 5.8 & 5.2 & 1.7 & 2.2 \\
\hline
\end{tabular}

$\mathrm{IQR}=$ Interquartile range

aKiel Obesity Prevention Study.

bBetter diet. More exercise. KINDERLEICHT-REGIONS.

cExamination of Jena schoolchildren.

we draw a randomly selected sample from our pooled data with prevalence of overweight and obesity in every 1-year age group according to the German Health Interview and Examination Survey for Children and Adolescents (KiGGS) [18], a population-based, nationally representative cross-sectional health examination survey carried out from May 2003 to May 2006. This sample, hereinafter referred to as reference population 1, included 23,236 children and adolescents (11,632 girls and 11,604 boys) aged 3-16 years.

A reference population 2 (table 2) was created to derive further body fat percentiles. The sample for this reference 2 was randomly selected to match the expected overweight prevalence of the national BMI reference of $10 \%$ in every age group [19]. In contrast to the recent KiGGS study, the German BMI reference based on an older reference population for German children and adolescents (acquisition period 19851997). This reference population 2 included 23,930 children and adolescents (12,069 girls and 11,861 boys) aged 3-16 years.

\section{Anthropometry}

Anthropometric measurements were performed by trained staff following standard procedures. Body weight was measured to the nearest $0.1 \mathrm{~kg}$ using a calibrated electronic scale with subjects wearing minimal clothing. Body height was sized to the nearest $0.5 \mathrm{~cm}$ (Kiel) or $0.1 \mathrm{~cm}$ (Jena). BMI was calculated from weight and height as $\mathrm{kg} / \mathrm{m}^{2}$. Prevalence of overweight was defined as children and adolescents above the 90th percentile of the German sex-specific BMI for age growth charts [19]. In all studies, BIA was conducted with body impedance analyzer BIA 2000-C (Data Input, Frankfurt/M., Germany), which is a tetrapolar bioimpedance analyzer using hand to foot electrodes. Subjects were measured in the morning and for ethical reasons without fasting. Percentage body fat mass was calculated from BIA data using a 
Table 2. Characteristics of the reference population 2 (adapted to the German BMI reference) stratified to the single studies

\begin{tabular}{|c|c|c|c|c|c|c|}
\hline & \multicolumn{2}{|l|}{ KOPS } & \multicolumn{2}{|c|}{ KINDERLEICHT-REGIONS } & \multicolumn{2}{|l|}{ Jenac } \\
\hline & boys & girls & boys & girls & boys & girls \\
\hline Acquisition period & 1996-2008 & & 2007 & & 2005 & \\
\hline Sample size & 6,526 & 6,749 & 4,506 & 4,508 & 829 & 812 \\
\hline $\begin{array}{l}\text { Median age, years } \\
\text { (IQR) }\end{array}$ & $\begin{array}{l}10.11 \\
(6.56-14.30)\end{array}$ & $\begin{array}{l}10.04 \\
(6.49-14.21)\end{array}$ & $\begin{array}{l}7.17 \\
(5.17-7.92)\end{array}$ & $\begin{array}{l}7.08 \\
(5.08-7.83)\end{array}$ & $\begin{array}{l}6.93 \\
(4.83-10.22)\end{array}$ & $\begin{array}{l}6.23 \\
(4.81-9.61)\end{array}$ \\
\hline $\begin{array}{l}\text { Median height, } \mathrm{m} \\
\text { (IQR) }\end{array}$ & $\begin{array}{l}1.43 \\
(1.24-1.68)\end{array}$ & $\begin{array}{l}1.42 \\
(1.23-1.62)\end{array}$ & $\begin{array}{l}1.24 \\
(1.14-1.31)\end{array}$ & $\begin{array}{l}1.23 \\
(1.13-1.29)\end{array}$ & $\begin{array}{l}1.25 \\
(1.10-1.43)\end{array}$ & $\begin{array}{l}1.20 \\
(1.09-1.40)\end{array}$ \\
\hline $\begin{array}{l}\text { Median weight, kg } \\
\text { (IQR) }\end{array}$ & $\begin{array}{l}35.4 \\
(24.8-54.8)\end{array}$ & $\begin{array}{l}35.2 \\
(24.2-52.2)\end{array}$ & $\begin{array}{l}24.4 \\
(20.0-28.2)\end{array}$ & $\begin{array}{l}23,7 \\
(19.5-27.8)\end{array}$ & $\begin{array}{l}25.0 \\
(18.5-34.5)\end{array}$ & $\begin{array}{l}23.5 \\
(18.4-32.9)\end{array}$ \\
\hline $\begin{array}{l}\text { Median BMI, kg/m² } \\
\text { (IQR) }\end{array}$ & $\begin{array}{l}17.4 \\
(15.6-19.9)\end{array}$ & $\begin{array}{l}17.6 \\
(15.7-20.0)\end{array}$ & $\begin{array}{l}15.9 \\
(15.0-17.1)\end{array}$ & $\begin{array}{l}15.9 \\
(14.9-17.1)\end{array}$ & $\begin{array}{l}16.1 \\
(15.1-17.3)\end{array}$ & $\begin{array}{l}16.1 \\
(15.0-17.5)\end{array}$ \\
\hline $\begin{array}{l}\text { Median BMI-SDS } \\
\text { (IQR) }\end{array}$ & $\begin{array}{l}0.05 \\
(-0.54 \text { to } 0.70)\end{array}$ & $\begin{array}{l}0.10 \\
(-0.49 \text { to } 0.72)\end{array}$ & $\begin{array}{l}0.08 \\
(-0.49 \text { to } 0.72)\end{array}$ & $\begin{array}{l}0.10 \\
(-0.49 \text { to } 0.74)\end{array}$ & $\begin{array}{l}-0.05 \\
(-0.64 \text { to } 0.50)\end{array}$ & $\begin{array}{l}0.04 \\
(-0.59 \text { to } 0.61)\end{array}$ \\
\hline Overweight, \% & 6.9 & 7.0 & 7.1 & 6.9 & 5.5 & 6.5 \\
\hline Obesity, \% & 3.3 & 3.1 & 3.1 & 3.6 & 1.1 & 2.0 \\
\hline
\end{tabular}

$\mathrm{IQR}=$ Interquartile range

aiel Obesity Prevention Study.

bBetter diet. More exercise. KINDERLEICHT-REGIONS.

cExamination of Jena schoolchildren.

KOPS-population-based algorithm. For BIA measurement, inclusion criteria were BIA resistance values between $>400$ and $<1,000 \Omega$, phase angle among $>2^{\circ}$ and $<9^{\circ}$, (reactance/resistance) $\times 100 \leqq 15 \%$, and appropriate hand and foot resistance during BIA measurement and fat mass $\geq 5 \%$.

\section{Generation of the Population-Specific Algorithm to Calculate Fat Mass}

Regression equation for prediction of fat free mass (FFM; kg) measured by air displacement plethysmography (ADP) from impedance results was derived in a randomly selected sample of 158 children (88 females and 70 males) between 5 and 18 years (mean age $10.8 \pm 3.1$ years) and cross-validated in the remaining group of 79 children ( 45 females and 34 males) between 4 and 18 years (mean age $10.5 \pm 3.4$ years). The number of subjects in the cross-validation group was estimated as follows: To detect a true mean difference of $1.5 \pm 3 \mathrm{~kg}$ between the predicted and the measured FFM at a significance level of 0.05 and $80 \%$ power, 63 children are needed for cross-validation. Thus our target sample size of 79 children may be considered adequate for cross-validating the developed FFM prediction equation. Samples for generation of the equation and its cross-validation did not differ with respect to age, weight, height, BMI, $\mathrm{R}^{2} / \mathrm{H}, \mathrm{R}, \mathrm{Xc}$ and $\%$ fat mass measured by ADP. Stepwise multiple regression analysis was used to determine the optimal combination of prediction parameters to fit the model. Coefficient of determination $\left(\mathrm{R}^{2}=\right.$ proportion of the total variance in the dependent variable that is explained by the independent variables) and the standard error of estimate (SEE) were calculated, and predictor variables were included in the model only if their addition resulted in a significant increase in the explained variance of the dependent variable (FFM) and a substantial change $(>10 \%)$ in $\beta$-coefficients of independent variables. Pure error, which is a measure of the performance of the prediction equation when applied to the independent cross- 
validation sample, was calculated as the square root of the sum of squared differences between the observed and the predicted values divided by the number of subjects in the cross-validation sample [20].

Mean values for measured and predicted FFM were compared by paired Student's t test. The agreement between measured and predicted values was further examined by residual plots (residuals were plotted against the predicted values) that were analyzed for curvilinearity (by adding the square term of the predicted variable to the original model and testing for its significance) and heteroscedasticity (by dividing the sample by a median split of the predicted variable and testing for homogeneity of variances using Levene's test).

The resulting algorithm was:

FFM $(\mathrm{kg})=0.66\left(\right.$ height $\left.^{2} / \mathrm{R}\right)+0.196 \times$ weight $+0.157 \times \mathrm{Xc}+0.348 \times$ age -12.083

with height in cm; weight in kg; R (resistance) and Xc (reactance) in ohm; age in years

For this final algorithm $\mathrm{R}^{2}$ was 0.95 , SEE was $2.97 \mathrm{~kg}$ and pure error was $2.74 \mathrm{~kg}$. Sex did not significantly contribute to the variance and was excluded as a predicting variable in the final model. Residuals between predicted and measured FFM were not significantly related to the predicted dependent variable, and the independent variables with the exception of weight $(r=0.29 ; p<0.01)$. Test for curvilinearity of the residual plot was not significant $(p=0.35)$. Also Levene's test for homoscedasticity was not significant $(p=0.64)$. Mean difference between measured and predicted FFM did not differ between sexes in the cross-validation group $(0.20 \pm 2.2 \mathrm{~kg} \mathrm{FFM}$ for girls and $-0.47 \pm 3.4 \mathrm{~kg} \mathrm{FFM}$ for boys; $\mathrm{p}=0.13)$. In the whole group the equation generation bias was $-0.01 \pm 2.93 \mathrm{~kg}$ FFM. In the cross-validation subgroup it was $-0.088 \pm 2.75 \mathrm{~kg}$ FFM with no significant differences between groups. Fat mass was then calculated as the difference between body weight and FFM.

\section{Modelling of Fat Mass Percentiles}

The age-specific percentile curves were modeled by the LMS method [21]. They are summarized by three curves representing the median (M), the coefficient of variation (S), and the skewness (L) as they change with age. The three curves can be fitted as cubic splines by non-linear regression. $\mathrm{C} \alpha(\mathrm{t})$, the $(100 \alpha)$-centile at age $t$, is given by:

$$
C_{\alpha}(t)=M(t) \cdot\left(1+L(t) \cdot S(t) \cdot z_{\alpha}\right)^{\frac{1}{L(t)}}
$$

for $\mathrm{L}(\mathrm{t}) \neq 0$. $\mathrm{z} \alpha$ is the $\alpha$-quantile of a standard normal distribution. For an individual fat mass (FM) at age $\mathrm{t}$ the $\mathrm{z}$-score or SDS can be calculated as:

$$
S D S_{L M S}=\frac{(F M / M(t))^{L(t)}-1}{L(t) \cdot S(t)}
$$

for $L(t) \neq 0$. The goodness-of-fit was examined by the visual inspection of the percentiles, a graphical comparison of the empirical and the fitted centiles, the analysis of the percentage of data outside the smoothed percentiles, by Q-tests [22] and worm plots [23].

\section{Disease-Related Cut-Offs}

To calculate cut-offs for overfat according to disease risk, data on blood pressure were used which were available for the KOPS cohort $(n=7,371$, boys $=3,487$, girls $=3,884)$. Blood pressure was measured using a sphygmomanometer on the right arm after a 5-min rest. Hypertension was defined by the agespecific 95th percentile for systolic and diastolic blood pressure as recommended by the Second Task Force on Blood Pressure Control in Children [24]. To define blood pressure-related cut-offs for overfat sensitivity and specificity were calculated.

\section{Statistics}

Statistical analyses were performed with SPSS 15.0 for Windows (SPSS, Inc., Chicago, IL, USA). The LMS model was fitted by the R Project for Statistical Computing version 2.11.0 (www.r-project.org) using the gamlss package [25]. Results were presented as median and interquartile range (IQR). Sensitivity and specificity was calculated for BMI and fat mass as well as for fat mass and blood pressure. Sensitivity measures the percentage of diseased people which were correctly identified as having the condition. Specificity quantifies the percentage of healthy people which were correctly detected as not having the condition. Level of significance was set at $\mathrm{p}<0.05$ (two-sided). 
Table 3. Characteristics of the reference population 1 (median, IQR)

\begin{tabular}{|c|c|c|c|c|c|}
\hline $\begin{array}{l}\text { 1-year age } \\
\text { groups }\end{array}$ & $\begin{array}{l}\text { Sample } \\
\text { size, n }\end{array}$ & Height, m & Weight, kg & BMI, $\mathrm{kg} / \mathrm{m}^{2}$ & Body fat, $\%$ \\
\hline \multicolumn{6}{|l|}{ Boys } \\
\hline 3.0-3.99 & 558 & $1.01(0.98-1.04)$ & $16.2(14.9-17.3)$ & $15.7(15.1-16.6)$ & $31.4(26.6-36.2)$ \\
\hline $4.0-4.99$ & 821 & $1.07(1.04-1.11)$ & $17.9(16.5-19.5)$ & $15.5(14.7-16.4)$ & $26.1(21.3-30.5)$ \\
\hline $5.0-5.99$ & 1,006 & $1.17(1.13-1.21)$ & $21.0(19.2-23.0)$ & $15.4(14.7-16.4)$ & $21.5(17.8-25.7)$ \\
\hline $6.0-6.99$ & 2,458 & $1.22(1.18-1.25)$ & $23.0(21.0-25.6)$ & $15.6(14.7-16.4)$ & $20.4(16.4-24.7)$ \\
\hline $7.0-7.99$ & 1,721 & $1.27(1.23-1.31)$ & $26.3(23.7-29.6)$ & $16.1(15.1-17.5)$ & $18.8(14.3-23.8)$ \\
\hline 8.0-8.99 & 1,090 & 1.33 (1.29-1.37) & $29.2(26.1-33.6)$ & $16.5(15.3-18.5)$ & $18.8(13.9-25.0)$ \\
\hline $9.0-9.99$ & 1,144 & $1.41(1.36-1.45)$ & $33.4(29.9-38.6)$ & $16.9(15.7-18.9)$ & $18.7(14.1-24.7)$ \\
\hline $10.0-10.99$ & 979 & $1.44(1.40-1.49)$ & $36.0(32.0-41.8)$ & $17.3(15.9-19.5)$ & $19.7(15.2-26.3)$ \\
\hline 11.0-11.99 & 230 & $1.49(1.43-1.54)$ & $39.6(34.8-46.1)$ & $17.8(16.1-20.1)$ & $19.4(14.3-26.0)$ \\
\hline $12.0-12.99$ & 42 & $1.55(1.50-1.64)$ & $46.6(39.4-55.8)$ & $18.9(16.9-21.6)$ & $17.9(10.3-26.5)$ \\
\hline 13.0-13.99 & 151 & $1.68(1.62-1.74)$ & $56.5(48.4-66.0)$ & $19.9(18.2-22.3)$ & $17.7(13.1-23.9)$ \\
\hline $14.0-14.99$ & 1,011 & $1.72(1.67-1.77)$ & $60.9(53.2-69.2)$ & $20.3(18.5-22.7)$ & $17.6(13.9-23.8)$ \\
\hline $15.0-15.99$ & 393 & $1.74(1.70-1.80)$ & 64.7 (57.1-72.8) & $20.9(19.1-23.3)$ & $17.8(13.8-23.2)$ \\
\hline \multicolumn{6}{|l|}{ Girls } \\
\hline 3.0-3.99 & 546 & $1.00(0.97-1.03)$ & $15.7(14.5-17.2)$ & $15.7(14.9-16.7)$ & $31.2(25.2-36.0)$ \\
\hline $4.0-4.99$ & 742 & $1.07(1.04-1.11)$ & $17.7(16.2-19.5)$ & $15.5(14.6-16.4)$ & $26.1(21.4-30.4)$ \\
\hline $5.0-5.99$ & 1,023 & $1.16(1.13-1.20)$ & $20.9(19.0-23.0)$ & $15.5(14.6-16.5)$ & $21.7(16.7-26.4)$ \\
\hline $6.0-6.99$ & 2,446 & $1.21(1.17-1.24)$ & $22.8(20.7-25.5)$ & $15.7(14.7-16.9)$ & $21.1(16.3-25.9)$ \\
\hline $7.0-7.99$ & 1,602 & $1.26(1.22-1.30)$ & $25.8(23.0-29.0)$ & $16.0(15.0-17.5)$ & $19.8(15.4-25.0)$ \\
\hline 8.0-8.99 & 997 & $1.32(1.23-1.36)$ & $28.5(25.3-32.8)$ & $16.3(15.1-18.2)$ & $19.8(14.6-25.7)$ \\
\hline $9.0-9.99$ & 1,228 & $1.40(1.36-1.44)$ & $33.4(29.4-39.2)$ & $17.1(15.7-19.1)$ & $21.2(16.0-27.4)$ \\
\hline $10.0-10.99$ & 903 & $1.44(1.39-1.49)$ & $36.8(32.1-43.0)$ & $17.7(16.2-20.0)$ & $22.8(17.5-28.8)$ \\
\hline 11.0-11.99 & 174 & $1.49(1.45-1.55)$ & $41.0(35.3-48.7)$ & $18.0(16.1-20.6)$ & $20.6(15.5-29.4)$ \\
\hline $12.0-12.99$ & 20 & $1.56(1.54-1.60)$ & $47.3(39.6-52.3)$ & $19.0(16.7-21.1)$ & $17.7(12.2-24.9)$ \\
\hline 13.0-13.99 & 256 & $1.64(1.60-1.69)$ & $54.5(49.2-61.5)$ & $20.0(18.4-22.7)$ & $24.6(20.2-29.5)$ \\
\hline $14.0-14.99$ & 1,289 & $1.65(1.61-1.70)$ & $55.6(50.4-62.3)$ & $20.3(18.8-22.5)$ & $25.1(21.2-29.7)$ \\
\hline $15.0-15.99$ & 406 & 1.65 (1.61-1.69) & $58.1(52.3-64.5)$ & $21.3(19.5-23.5)$ & $27.0(23.0-31.1)$ \\
\hline
\end{tabular}

$\mathrm{IQR}=$ Interquartile range.

\section{Results}

The sample size in each age group and characteristics of the reference population 1 are shown in table 3. Children and adolescents were well distributed over the age range, except for age 12 years with few data only.

The sex-specific smoothed percentage body fat percentiles by age are displayed in fig. 1 . Table 4 and 5 show the tabulated percentage body fat percentile values for boys and girls aged 3-16 years in 6-month steps. In both genders, the higher body fat percentile curves sloped downwards to age 7 years, whereas the lower percentiles declined up to age 8.5 years. After that age fat mass remained similarly constant with age in boys and increased steadily in girls. In boys and girls the higher percentile curves showed a local maximum at age 11 years. The 90 th percentile curve fluctuates between 29 and $44 \%$ in boys or $30-43 \%$ of fat mass in girls, whereas the 10 th percentile achieved a minimum of $10-11 \%$ body fat. At age 4-16 years body fat of girls was higher than that of boys. 
Table 4. Smoothed body fat (\%) percentile values for German boys aged 3-16 years in 6-month steps

\begin{tabular}{|c|c|c|c|c|c|c|c|c|c|}
\hline Age, years & $\mathrm{L}$ & $\mathrm{S}$ & P3 & P10 & $\mathrm{P} 25$ & P50 (M) & P75 & P90 & P97 \\
\hline 3 & 1.35 & 0.22 & 18.94 & 24.27 & 29.29 & 34.54 & 39.53 & 43.84 & 47.96 \\
\hline 3.5 & 1.25 & 0.23 & 16.69 & 21.63 & 26.36 & 31.39 & 36.22 & 40.43 & 44.48 \\
\hline 4 & 1.15 & 0.25 & 14.62 & 19.15 & 23.58 & 28.36 & 33.03 & 37.13 & 41.12 \\
\hline 4.5 & 1.06 & 0.26 & 12.83 & 16.99 & 21.15 & 25.72 & 30.25 & 34.29 & 38.25 \\
\hline 5 & 0.96 & 0.28 & 11.40 & 15.23 & 19.17 & 23.58 & 28.03 & 32.07 & 36.07 \\
\hline 5.5 & 0.85 & 0.30 & 10.33 & 13.90 & 17.67 & 22.00 & 26.45 & 30.56 & 34.69 \\
\hline 6 & 0.76 & 0.31 & 9.58 & 12.96 & 16.62 & 20.93 & 25.47 & 29.74 & 34.10 \\
\hline 6.5 & 0.66 & 0.33 & 9.01 & 12.23 & 15.81 & 20.15 & 24.82 & 29.31 & 33.97 \\
\hline 7 & 0.58 & 0.35 & 8.52 & 11.60 & 15.12 & 19.49 & 24.32 & 29.04 & 34.05 \\
\hline 7.5 & 0.50 & 0.37 & 8.11 & 11.09 & 14.57 & 19.00 & 24.00 & 29.00 & 34.39 \\
\hline 8 & 0.45 & 0.38 & 7.86 & 10.78 & 14.27 & 18.79 & 24.00 & 29.30 & 35.10 \\
\hline 8.5 & 0.41 & 0.40 & 7.76 & 10.66 & 14.18 & 18.81 & 24.23 & 29.81 & 36.01 \\
\hline 9 & 0.38 & 0.40 & 7.73 & 10.64 & 14.19 & 18.90 & 24.47 & 30.27 & 36.76 \\
\hline 9.5 & 0.36 & 0.41 & 7.80 & 10.72 & 14.31 & 19.10 & 24.81 & 30.78 & 37.50 \\
\hline 10 & 0.35 & 0.41 & 7.92 & 10.89 & 14.53 & 19.42 & 25.25 & 31.39 & 38.31 \\
\hline 10.5 & 0.35 & 0.41 & 8.04 & 11.03 & 14.72 & 19.69 & 25.63 & 31.89 & 38.98 \\
\hline 11 & 0.34 & 0.41 & 8.06 & 11.05 & 14.75 & 19.74 & 25.72 & 32.05 & 39.22 \\
\hline 11.5 & 0.33 & 0.41 & 8.01 & 10.97 & 14.63 & 19.57 & 25.53 & 31.85 & 39.04 \\
\hline 12 & 0.31 & 0.41 & 7.94 & 10.83 & 14.42 & 19.28 & 25.16 & 31.42 & 38.56 \\
\hline 12.5 & 0.30 & 0.41 & 7.88 & 10.69 & 14.19 & 18.95 & 24.72 & 30.89 & 37.97 \\
\hline 13 & 0.28 & 0.41 & 7.86 & 10.59 & 14.00 & 18.64 & 24.30 & 30.37 & 37.37 \\
\hline 13.5 & 0.26 & 0.40 & 7.88 & 10.53 & 13.85 & 18.38 & 23.93 & 29.91 & 36.84 \\
\hline 14 & 0.23 & 0.40 & 7.92 & 10.51 & 13.74 & 18.69 & 23.62 & 29.53 & 36.42 \\
\hline 14.5 & 0.21 & 0.40 & 7.97 & 10.49 & 13.65 & 18.00 & 23.38 & 29.24 & 36.11 \\
\hline 15 & 0.18 & 0.40 & 8.02 & 10.50 & 13.60 & 17.89 & 23.23 & 29.07 & 35.97 \\
\hline 15.5 & 0.16 & 0.40 & 8.10 & 10.54 & 13.62 & 17.89 & 23.23 & 29.11 & 36.10 \\
\hline 16 & 0.14 & 0.39 & 8.19 & 10.62 & 13.68 & 17.94 & 23.31 & 29.26 & 36.37 \\
\hline
\end{tabular}
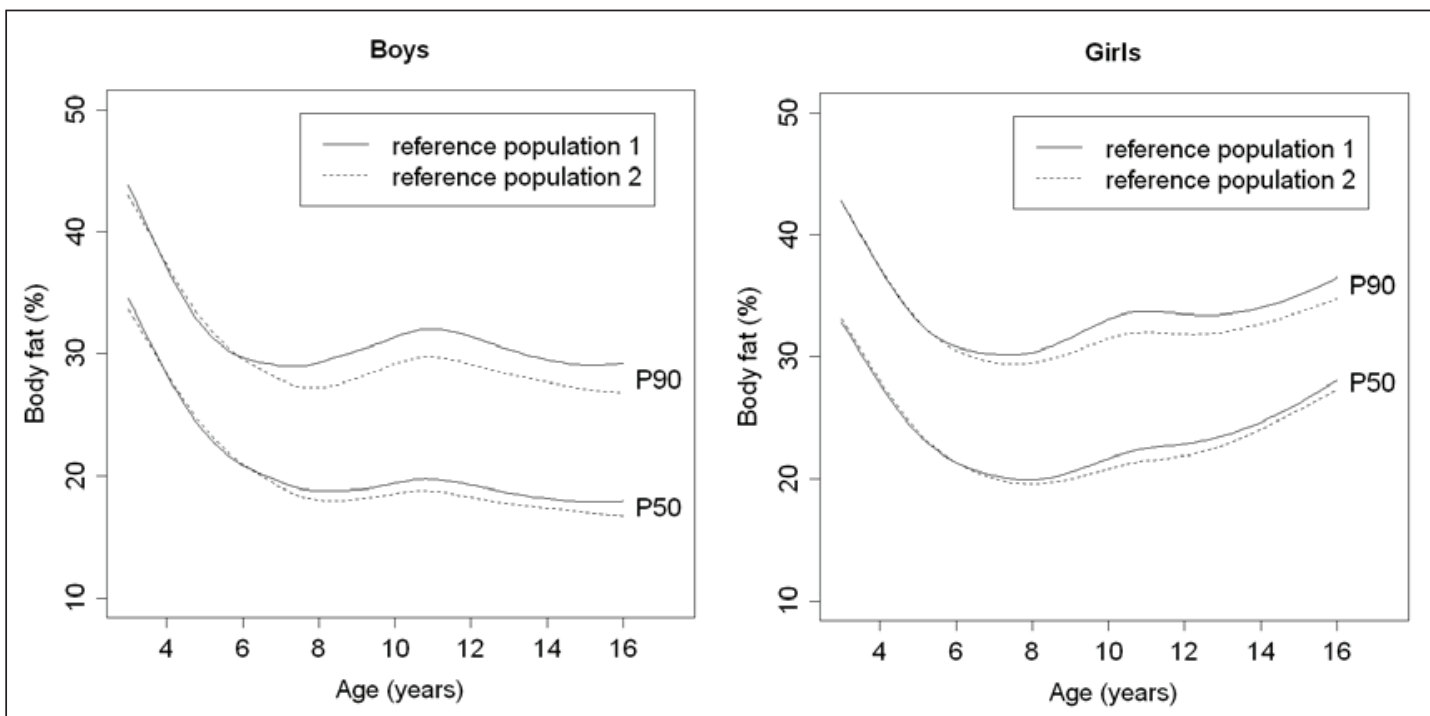

Fig. 1. Smoothed body fat (\%) percentile curves for German boys and girls aged 3-16 years. 
Table 5. Smoothed body fat (\%) percentile values for German girls aged 3-16 years in 6-month steps

\begin{tabular}{|c|c|c|c|c|c|c|c|c|c|}
\hline Age, years & $\mathrm{L}$ & $\mathrm{S}$ & P3 & P10 & P25 & P50 (M) & P75 & P90 & P97 \\
\hline 3 & 1.47 & 0.25 & 15.22 & 21.41 & 27.10 & 32.86 & 38.20 & 42.73 & 46.98 \\
\hline 3.5 & 1.35 & 0.26 & 13.71 & 19.41 & 24.75 & 30.29 & 35.50 & 39.97 & 44.21 \\
\hline 4 & 1.23 & 0.28 & 12.33 & 17.53 & 22.52 & 27.81 & 32.88 & 37.29 & 41.52 \\
\hline 4.5 & 1.12 & 0.29 & 11.15 & 15.86 & 20.53 & 25.58 & 30.52 & 34.89 & 39.15 \\
\hline 5 & 1.00 & 0.30 & 10.19 & 14.48 & 18.85 & 23.72 & 28.57 & 32.95 & 37.26 \\
\hline 5.5 & 0.90 & 0.32 & 9.49 & 13.44 & 17.59 & 22.33 & 27.17 & 31.60 & 36.04 \\
\hline 6 & 0.80 & 0.33 & 9.02 & 12.72 & 16.72 & 21.39 & 26.28 & 30.85 & 35.49 \\
\hline 6.5 & 0.72 & 0.34 & 8.69 & 12.21 & 16.09 & 20.75 & 25.73 & 30.45 & 35.33 \\
\hline 7 & 0.65 & 0.36 & 8.44 & 11.82 & 15.63 & 20.29 & 25.35 & 30.24 & 35.36 \\
\hline 7.5 & 0.60 & 0.37 & 8.24 & 11.54 & 15.31 & 19.99 & 25.15 & 30.19 & 35.52 \\
\hline 8 & 0.58 & 0.37 & 8.12 & 11.40 & 15.19 & 19.93 & 25.20 & 30.38 & 35.90 \\
\hline 8.5 & 0.57 & 0.38 & 8.12 & 11.44 & 15.30 & 20.14 & 25.54 & 30.87 & 36.55 \\
\hline 9 & 0.58 & 0.38 & 8.21 & 11.63 & 15.60 & 20.57 & 26.11 & 31.57 & 37.39 \\
\hline 9.5 & 0.59 & 0.38 & 8.39 & 11.93 & 16.02 & 21.12 & 26.79 & 32.35 & 38.26 \\
\hline 10 & 0.61 & 0.37 & 8.65 & 12.30 & 16.50 & 21.71 & 27.47 & 33.10 & 39.05 \\
\hline 10.5 & 0.62 & 0.37 & 8.94 & 12.67 & 16.93 & 22.19 & 27.97 & 33.59 & 39.52 \\
\hline 11 & 0.63 & 0.36 & 9.26 & 13.02 & 17.28 & 22.51 & 28.23 & 33.77 & 39.58 \\
\hline 11.5 & 0.64 & 0.35 & 9.63 & 13.36 & 17.57 & 22.70 & 28.28 & 33.68 & 39.32 \\
\hline 12 & 0.65 & 0.34 & 10.10 & 13.78 & 17.89 & 22.89 & 28.31 & 33.52 & 38.97 \\
\hline 12.5 & 0.64 & 0.32 & 10.71 & 14.30 & 18.31 & 23.16 & 28.40 & 33.44 & 38.70 \\
\hline 13 & 0.63 & 0.31 & 11.44 & 14.95 & 18.84 & 23.55 & 28.62 & 33.49 & 38.57 \\
\hline 13.5 & 0.62 & 0.29 & 12.30 & 15.73 & 19.51 & 24.07 & 28.98 & 33.70 & 38.61 \\
\hline 14 & 0.60 & 0.28 & 13.26 & 16.60 & 20.28 & 24.70 & 29.46 & 34.03 & 38.79 \\
\hline 14.5 & 0.58 & 0.26 & 14.29 & 17.55 & 21.13 & 25.42 & 30.05 & 34.48 & 39.11 \\
\hline 15 & 0.56 & 0.25 & 15.39 & 18.57 & 22.06 & 26.25 & 30.75 & 35.07 & 39.57 \\
\hline 15.5 & 0.54 & 0.23 & 16.54 & 19.66 & 23.08 & 27.16 & 31.56 & 35.77 & 40.17 \\
\hline 16 & 0.52 & 0.22 & 17.71 & 20.76 & 24.10 & 28.09 & 32.38 & 36.49 & 40.79 \\
\hline
\end{tabular}

Table 6. Sensitivity and specificity of body fat and BMI (cut-off: P90) predicting elevated blood pressure (cut-off: P95)

\begin{tabular}{|c|c|c|c|c|}
\hline & \multicolumn{2}{|l|}{ Boys } & \multicolumn{2}{|l|}{ Girls } \\
\hline & sensitivity & specificity & sensitivity & specificity \\
\hline Body fat from reference population 1 & $24 \%$ & $91 \%$ & $24 \%$ & $91 \%$ \\
\hline Body fat from reference population 2 & $31 \%$ & $87 \%$ & $30 \%$ & $88 \%$ \\
\hline BMI (KiGGS*) & $26 \%$ & $92 \%$ & $32 \%$ & $91 \%$ \\
\hline BMI (German reference**) & $36 \%$ & $86 \%$ & $35 \%$ & $86 \%$ \\
\hline
\end{tabular}

*KiGGS (German Health Interview and Examination Survey for Children and Adolescents).

**German BMI reference [19]. 


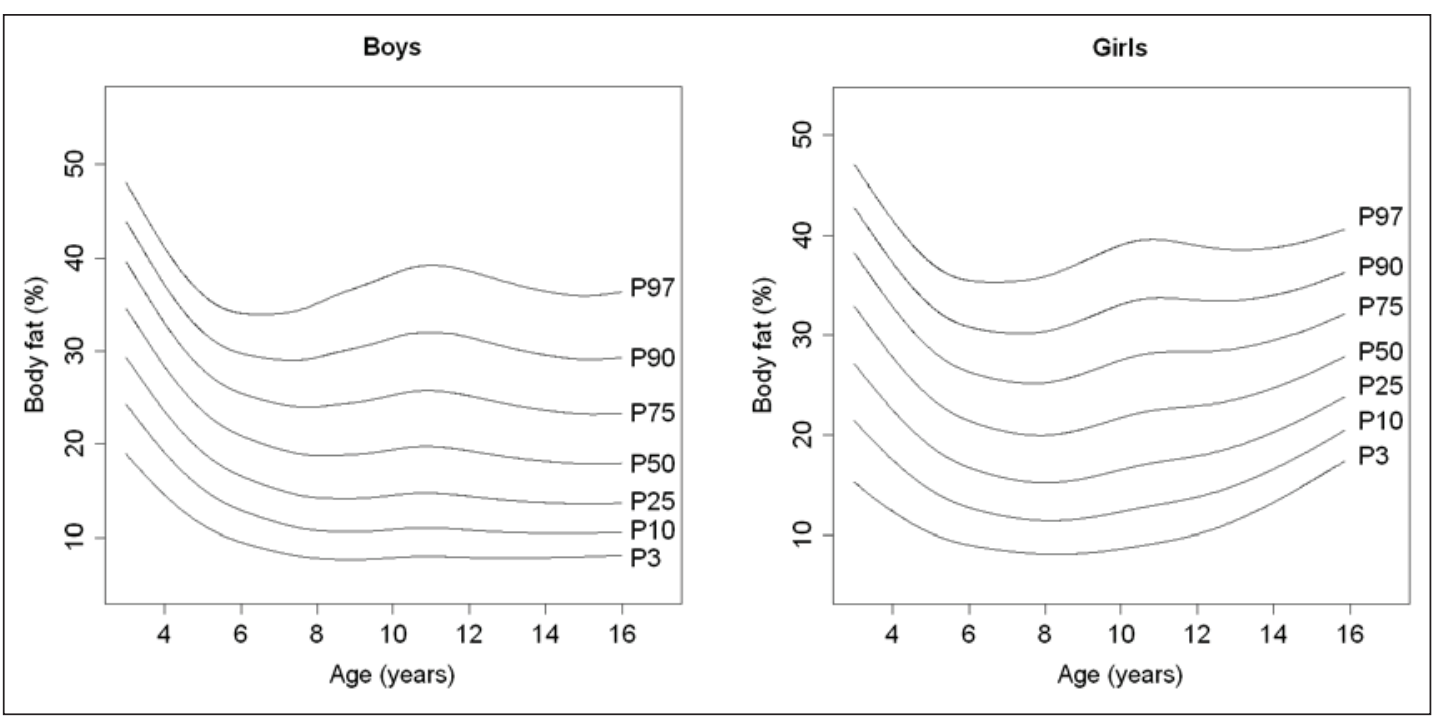

Fig. 2. Comparison of the 50th and 90th percentile of fat mass from reference population 1 (adapted to KiGGS) and reference population 2 (adapted to the German BMI reference) in boys and girls.

Comparing the 50th and 90 th percentile curves of body fat fitted from reference population 1 and 2, the shape of the percentiles was similar (fig. 2). Up to age 6 years the 90th percentiles were nearly identical. Thereafter, the 90th body fat percentile curve of the more recent reference population (reference population 1) was higher than that of reference population 2 . Generally, the 90 th body fat percentile curves had a mean deviation of $1.5 \%$ and $1 \%$ in boys and girls, respectively. The maximum difference of the 90 th percentiles was among boys at age 16 years (2.48\%) and among girls at age 11 and 16 years $(1.73 \%)$.

Sensitivities of body fat as well as of BMI predicting blood pressure were very low (table 6). Sensitivity was lower when the recent reference population 1 was used compared to reference population 2. Sensitivity did not increase with age (data not shown). Specificities were sufficient.

\section{Discussion}

Sex- and Age-Specific Run of the Fat Mass Percentile Curves

In this study, sex-specific smoothed percentile values and curves for body fat measured by BIA were presented for German children and adolescents aged 3-16 years (fig. 1). We found that girls at or above the 90th percentile curves from the age of 4 years had a higher body fat mass than boys. By contrast, up to age 6 years boys had a higher fat mass than girls at the lower percentiles. Some authors reported similar results $[9,10]$ but others showed a higher percentage of body fat mass in girls compared to boys over the entire age range [8, $11,12]$. As changes in body composition during growth are expected, body fat percentiles showed a considerable decrease in infancy. In both genders, the higher body fat percentiles reached the 'break point' 1.5 years earlier than the lower percentiles, corresponding to the known adiposity rebound. After that age, decreases in body fat remained nearly constant with age in boys and increased steadily in girls. This gender-specific difference might be due to changes in sex hormones during adolescence affecting body composition. In puberty, boys 
Table 7. Comparison of characteristics of studies that developed fat mass percentiles

\begin{tabular}{|c|c|c|c|c|}
\hline & USA [7] & UK [8] & Poland [9] & Hong Kong [10] \\
\hline Study & NHANES III & 21 schools & 2 schools & $\begin{array}{l}36 \text { schools }+ \\
1 \text { teaching hospital }\end{array}$ \\
\hline Acquisition period & 1988-1994 & not reported & not reported & not reported \\
\hline Area & USA & southern England & Krakow & Hong Kong \\
\hline Sample size, $\mathrm{n}$ & 757 & 1,985 & 193 & 14,842 \\
\hline Age, years & $12-20$ & $5-18$ & $8-16$ & $6-18$ \\
\hline $\begin{array}{l}\text { Subjects per } 1 \text {-year } \\
\text { age group, } \mathrm{n}\end{array}$ & $\begin{array}{l}76-120 \\
\text { (per 2-year age group) }\end{array}$ & not reported & not reported & $324-749$ \\
\hline \multicolumn{5}{|l|}{ BIA } \\
\hline Device & Valhalla 1990B & Tanita BC-418 MA & $\begin{array}{l}\text { Data Input. BIA } \\
2000 \mathrm{M}\end{array}$ & Tanita BF-522 \\
\hline Measurement & hand to foot & hand to foot & hand to foot & foot to foot \\
\hline Algorithm & Sun et al., 2003 & $\begin{array}{l}\text { algorithm validated } \\
\text { against DXA }\end{array}$ & Nutri 4 software & $\begin{array}{l}\text { algorithm validated } \\
\text { against DXA }\end{array}$ \\
\hline Curve fitting & $\begin{array}{l}\text { Taylor Series lineariza- } \\
\text { tion (SUDAAN) }\end{array}$ & LMS (Chart Maker Pro) & LMS & LMS \\
\hline Percentile values & estimated means & $\begin{array}{l}\text { P2, P9, P25, P50, P75, } \\
\text { P91, P95, P98 }\end{array}$ & $\begin{array}{l}\text { P5, P10 ,P25, P50, } \\
\text { P75, P90, P95 }\end{array}$ & $\begin{array}{l}\text { P5, P10, P25, P50, P75, } \\
\text { P90, P95 }\end{array}$ \\
\hline \multirow[t]{2}{*}{$\begin{array}{c}\text { Prevalence of } \\
\text { overweight }\end{array}$} & not reported & $\begin{array}{l}\text { obesity rate close to the } \\
1990 \text { sample }\end{array}$ & not reported & $13 \%(\mathrm{IOTF})$ \\
\hline & Greece [11] & Turkey [12] & & Our study \\
\hline Study & 8 schools & DAMTCA II & & $\begin{array}{l}\text { KOPS; Better diet. More } \\
\text { exercise. KINDERLEICHT- } \\
\text { REGIONS; Jena school } \\
\text { examinations }\end{array}$ \\
\hline Acquisition period & not reported & $2007-2008$ & & $1996-2008$ \\
\hline Area & Thessaloniki & Kayseri & & Germany \\
\hline Sample size, $\mathrm{n}$ & 607 & 4,076 & & 23,236 \\
\hline Age, years & $7-15$ & $6-18$ & & $3-16$ \\
\hline $\begin{array}{l}\text { Subjects per 1-year } \\
\text { age group, } \mathrm{n}\end{array}$ & $\begin{array}{l}\text { 65-138 } \\
\text { (per 3-year age group) }\end{array}$ & $13-247$ & & $20-2,458$ \\
\hline \multicolumn{5}{|l|}{ BIA } \\
\hline Device & Maltron, BF-906 & Tanita, BC-418 MA & & Data Input, BIA 2000-C \\
\hline Measurement & hand to foot & hand to foot & & hand to foot \\
\hline Algorithm & not reported & $\begin{array}{l}\text { algorithm validated } \\
\text { against DXA }\end{array}$ & & $\begin{array}{l}\text { algorithm validated } \\
\text { against ADP }\end{array}$ \\
\hline Curve fitting & LMS & LMS (Chart Maker Pro) & & LMS (R) \\
\hline Percentile values & $\begin{array}{l}\text { P2, P9, P25, P50, P75, } \\
\text { P85, P91, P95, P98 }\end{array}$ & $\begin{array}{l}\text { P3, P5, P10 ,P25, P50, } \\
\text { P75, P85, P90, P75, P97 }\end{array}$ & & $\begin{array}{l}\text { P3, P10, P25, P50, P75, } \\
\text { P90, P97 }\end{array}$ \\
\hline $\begin{array}{c}\text { Prevalence of } \\
\text { overweight }\end{array}$ & not reported & not reported & & $8.2 \%(\mathrm{KH})$ \\
\hline
\end{tabular}




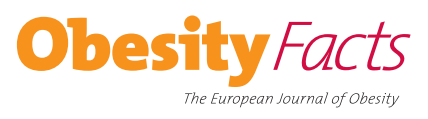

\begin{tabular}{l|l}
\hline Obes Facts 2012;5:77-90 \\
\hline DOI: 10.1159/000336780 & $\begin{array}{l}\text { @ 2012 S. Karger GmbH, Freiburg } \\
\text { www.karger.com/ofa }\end{array}$ \\
\hline Published online: March 2, 2012 &
\end{tabular}

gained proportionately more muscle and lean mass than fat mass, whereas girls have an increase of body fat mass [26]. The higher body fat percentile curves displayed a local maximum at age 11 years in both, boys and girls. Similar results have been shown for boys by other authors $[8,9,12]$.

\section{Use of Reference Population}

To ensure representativeness we adapted our study population to the actual prevalence of overweight in KiGGS (reference population 1). The KiGGS study population is a large population-based and nationally representative sample of German children and adolescents [27] while the prior used German BMI reference population is based on a study with some methodical problems (basis for reference population 2) [19]. It may be questioned if the use of reference population 1 is suitable because it reflects the actual fatness of our society and reference curves of body fat mass would be underestimated. Comparing the two reference populations, the 90th body fat percentile curves were higher in reference population 1 than in reference population 2 from the age of 6 years but there were only slight mean deviations between the 90 th body fat percentiles (fig. 2). Thus, we decided to present body fat percentiles of reference population 1 only.

\section{Disease-Related Cut-Offs for Overfat}

Up to now, disease-related cut-offs exist neither for BMI nor for body fat in children and adolescents. However, a positive association between body fat and blood pressure in children has been reported $[9,28,29]$. To define disease-related cut-offs for overfat we have calculated sensitivity and specificity of body fat predicting elevated blood pressure (table 6). Regarding the 90th percentile very low sensitivities could be shown only. This was independent of the reference population. Data were also in line with BMI-based calculations. Additionally, we have performed a Receiver Operating Characteristic (ROC) analysis. However, we could not determine disease-related cut-off points because suitable sensitivity and specificity values corresponded to very low and varying body fat percentiles (between 10 th and 90th percentile at different age groups). An explanation could be that the disease risk does not increase abruptly at an exact fat mass or BMI cut-off but rather continuously with increasing fat mass. In a very recent prospective study with a follow-up of 17 years risk of coronary heart disease at age 30 years was elevated in all subjects above the lowest BMI quintile at age 17 years [30]. These data question the idea of morbidity-defined cut-offs of fat mass in children and adolescents. By contrast, specificity was high. Thus, we can exclude a high blood pressure in those children with normal body fat. However, blood pressure should be checked in children with high body fat.

In addition, WC rather than fat mass or BMI may be considered as marker of disease risk since in children WC is a good predictor of visceral adipose tissue (VAT) which again is associated with health risks [31, 32]. By contrast, in children and adolescents, the association between either WC or BMI and blood pressure or plasma lipids was similar [33]. When compared with children and adolescents, the higher association between WC and disease risk in adults may be due to the high correlation of WC to VAT. However, children and adolescents have low VAT, and WC is of limited value as a risk estimate in this age group [34].

\section{Strengths and Limitations}

We compared our recent data with currently available data on body fat percentiles for children and adolescents which are based on BIA measurements from the EU, China and the USA [5, 8-12] (table 7). There are considerable differences between the studies due to the size (total number as well as subjects per age groups), prevalence of overweight, ethical background and advent of puberty of the study populations, BIA devices, and algorithms as 
well as modeling techniques affecting statistical power. Compared with these studies, the major strengths of our study are that we have used the currently largest German database with BIA measurements, the same BIA device in all study centers, and a population-specific algorithm as well as a huge and nationally representative sample of children and adolescents. Furthermore, the smoothed body fat percentiles were extensively monitored by statistical tests (goodness-of-fit criteria are given above).

By contrast, our study has also some limitations. For ethical reasons, a fasting condition was not a prerequisite for measurement. However, some authors found no significant differences in BIA estimates of body fat mass in adults and elderly persons between a fasting and a postprandial condition [35, 36]. In a previous study we had also compared the influence of meals on BIA measurements. We found that, when compared with fasting, meals slightly lowered resistance, but this did not result in a significant lower fat mass (Sawinski et al., unpublished data, 2002).

Another limitation of the study is the small sample size in the age group of 12.0-12.99 years. However, in this age group we have also approached the prevalence of overweight to the representative sample.

The present fat mass percentiles are considered as device- and country-specific. Thus, we would like to point out that our charts should not be used together with other BIA devices and algorithms (see also [8, 10, 11, 37]).

\section{Conclusions}

The present fat percentile curves define age- and gender-specific variances of body fat mass. Due to similar cut-off percentiles for the German body fat percentile curves derived from the German BMI percentiles [19] and the German WC percentiles based on KiGGS [38], we recommend to use the 90th and 97th sex-specific smoothed body fat percentile curves to identify overfat and obesity in children and adolescents. Our fat mass percentiles are suitable reference values for German children and adolescents and will help to further characterize pediatric obesity in clinical practice and epidemiological studies. The possible association between fat mass and metabolic disorders warrants a more systematic investigation in children and adolescents (including the assessment of specific fat depots).

\section{Contributors}

SPD and MJM had the original idea; SPD, MIG, BK, and ABW did the statistical analyses; MIG wrote the first draft of the paper together with SPD. SPD did the interpretation of the data, and wrote the final draft of the paper. CW and MG provided data of the project 'Better diet. More exercise. KINDERLEICHT-REGIONS' and contributed to the final draft of the paper. KKH provided data of the examination of Jena schoolchildren and contributed to the final draft of the paper. MJM supervised the study, did the interpretation of the data, and wrote the final draft of the paper. All authors discussed the data and approved the final version of the paper. MJM will act as guarantor for the paper.

\section{Acknowledgements}

KOPS was funded by the Deutsche Forschungsgemeinschaft (DFG Mü 5.1, 5.2, 5.3 and 5.5), 'Kompetenznetz Adipositas (Competence Network on Obesity)' funded by the Federal Ministry of Education and Research (FKZ: 01GI0821), WCRF, Wirtschaftliche Vereinigung Zucker. 'Better diet. More exercise. KINDERLEICHT-REGIONS' was funded by the German Federal Ministry of Food, Agriculture and Consumer Protection. The sponsors of the study had no role in study design, data collection, data analysis, data interpretation or writing of the paper. The corresponding author had full access to all the data in the study and had final responsibility for the decision to submit for publication. 


\section{Disclosure Statement}

The authors declared no conflict of interest.

\section{References}

- 1 Deurenberg P, Pieters JJ, Hautvast JG: The assessment of the body fat percentage by skinfold thickness measurements in childhood and young adolescence. Br J Nutr 1990;63:293-303.

- 2 Goran MI, Driscoll P, Johnson R, Nagy TR, Hunter G: Cross-calibration of body-composition techniques against dual-energy x-ray absorptiometry in young children. Am J Clin Nutr 1996;63:299-305.

- 3 Schaefer F, Georgi M, Zieger A, Scharer K: Usefulness of bioelectric impedance and skinfold measurements in predicting fat-free mass derived from total body potassium in children. Pediatr Res 1994;35:617-624.

4 Moreno LA, Mesana MI, Gonzalez-Gross M, Gil CM, Fleta J, Warnberg J, Ruiz JR, Sarria A, Marcos A, Bueno M: Anthropometric body fat composition reference values in Spanish adolescents. The AVENA study. Eur J Clin Nutr 2006;60:191-196.

5 Mueller WH, Harrist RB, Doyle SR, Labarthe DR: Percentiles of body composition from bioelectrical impedance and body measurements in U.S. adolescents 8-17 years old: Project Heartbeat! Am J Hum Biol 2004;16:135-150.

6 Kelly TL, Wilson KE, Heymsfield SB: Dual energy x-ray absorptiometry body composition reference values from NHANES. PLoS One 2009; 4:e7038.

7 Chumlea WC, Guo SS, Kuczmarski RJ, Flegal KM, Johnson CL, Heymsfield SB, Lukaski HC, Friedl K, Hubbard VS: Body composition estimates from NHANES III bioelectrical impedance data. Int J Obes Relat Metab Disord 2002;26:1596-1609.

8 McCarthy HD, Cole TJ, Fry T, Jebb SA, Prentice AM: Body fat reference curves for children. Int J Obes (Lond) 2006;30:598-602.

9 Drozdz D, Kwinta P, Korohoda P, Pietrzyk JA, Drozdz M, Sancewicz-Pach K: Correlation between fat mass and blood pressure in healthy children. Pediatr Nephrol 2009;24:1735-1740.

10 Sung RY, So HK, Choi KC, Li AM, Yin J, Nelson EA: Body fat measured by bioelectrical impedance in Hong Kong Chinese children. Hong Kong Med J 2009;15:110-117.

-11 Papandreou D, Malindretos P, Rousso I: First body fat percentiles for 607 children from Thessalonikinorthern Greece. Hippokratia 2010;14:208-211.

-12 Kurtoglu S, Mazicioglu MM, Ozturk A, Hatipoglu N, Cicek B, Ustunbas HB: Body fat reference curves for healthy Turkish children and adolescents. Eur J Pediatr 2010;169:1329-1335.

13 WHO: Obesity, Preventing and Managing a Global Epidemic. Report of a WHO consultation. Geneva, WHO, Technical Report Series 894. 2000.

14 Janssen I, Katzmarzyk PT, Srinivasan SR, Chen W, Malina RM, Bouchard C, Berenson GS: Utility of childhood BMI in the prediction of adulthood disease: comparison of national and international references. Obes Res 2005;13:1106-1115.

15 Danielzik S, Pust S, Landsberg B, Muller MJ: First lessons from the Kiel Obesity Prevention Study (KOPS). Int J Obes (Lond) 2005;29(suppl 2):S78-83.

16 Müller MJ, Asbeck I, Mast M, Langnäse K, Grund A: Prevention of obesity - more than an intention. Concept and first results of the Kiel Obesity Prevention Study (KOPS). Int J Obes Relat Metab Disord 2001;25(suppl 1):S66-74.

17 Würbach A, Zellner K, Kromeyer-Hauschild K: Meal patterns among children and adolescents and their associations with weight status and parental characteristics. Public Health Nutr 2009;12:1115-1121.

-18 Kurth BM, Kamtsiuris P, Holling H, Schlaud M, Dolle R, Ellert U, Kahl H, Knopf H, Lange M, Mensink GB, Neuhauser H, Rosario AS, Scheidt-Nave C, Schenk L, Schlack R, Stolzenberg H, Thamm M, Thierfelder W, Wolf U: The challenge of comprehensively mapping children's health in a nation-wide health survey: design of the German KiGGS-study. BMC Public Health 2008;8:196.

19 Kromeyer-Hauschild K, Wabitsch M, Kunze D, Geller F, Geiß H, Hesse V, von Hippel A, Jaeger U, Johnson D, Korte W, Menner K, Müller G, Müller MJ, Niemann-Pilatus A, Remer T, Schaefer F, Wittchen H-U, Zabransky S, Zellner K, Ziegler A, J. H: Perzentile für den Body Mass Index für das Kindes- und Jugendalter unter Heranziehung verschiedener deutscher Stichproben. Monatsschr Kinderheilkd 2001;149:807-818.

20 Guo SS, Chumlea WC, Cockram DB: Use of statistical methods to estimate body composition. Am J Clin Nutr 1996;64:428S-435S.

21 Cole TJ, Green PJ: Smoothing reference centile curves: The LMS method and penalized likelihood. Stat Med 1992;11:1305-1319.

22 Royston P, Wright EM: Goodness-of-fit statistics for age-specific reference intervals. Stat Med 2000;19: 2943-2962.

23 van Buuren S, Fredriks M: Worm plot: a simple diagnostic device for modelling growth reference curves. Stat Med 2001;20:1259-1277. 
Task Force on Blood Pressure Control in Children. National Heart, Lung, and Blood Institute, Bethesda, Maryland: Report of the Second Task Force on Blood Pressure Control in Children - 1987. Pediatrics 1987; 79:1-25.

25 Rigby RA, Stasinopoulos DM: Generalized additive models for location, scale and shape. Appl Statist 2005; 54:507-554.

-26 Demerath EW, Schubert CM, Maynard LM, Sun SS, Chumlea WC, Pickoff A, Czerwinski SA, Towne B, Siervogel RM: Do changes in body mass index percentile reflect changes in body composition in children? Data from the Fels Longitudinal Study. Pediatrics 2006;117:e487-495.

27 Schaffrath Rosario A, Kurth BM, Stolzenberg H, Ellert U, Neuhauser H: Body mass index percentiles for children and adolescents in Germany based on a nationally representative sample (KiGGS 2003-2006). Eur J Clin Nutr 2010;64:341-349.

-28 Eisenmann JC, Wrede J, Heelan KA: Associations between adiposity, family history of CHD and blood pressure in 3-8 year-old children. J Hum Hypertens 2005;19:675-681.

29 Sorof J, Daniels S: Obesity hypertension in children: a problem of epidemic proportions. Hypertension 2002;40:441-447.

-30 Tirosh A, Shai I, Afek A, Dubnov-Raz G, Ayalon N, Gordon B, Derazne E, Tzur D, Shamis A, Vinker S, Rudich A: Adolescent BMI trajectory and risk of diabetes versus coronary disease. N Engl J Med 2011;364:13151325.

-31 Brambilla P, Bedogni G, Moreno LA, Goran MI, Gutin B, Fox KR, Peters DM, Barbeau P, De Simone M, Pietrobelli A: Crossvalidation of anthropometry against magnetic resonance imaging for the assessment of visceral and subcutaneous adipose tissue in children. Int J Obes (Lond) 2006;30:23-30.

-32 Pischon T, Boeing H, Hoffmann K, Bergmann M, Schulze MB, Overvad K, van der Schouw YT, Spencer E, Moons KG, Tjonneland A, Halkjaer J, Jensen MK, Stegger J, Clavel-Chapelon F, Boutron-Ruault MC, Chajes V, Linseisen J, Kaaks R, Trichopoulou A, Trichopoulos D, Bamia C, Sieri S, Palli D, Tumino R, Vineis P, Panico S, Peeters PH, May AM, Bueno-de-Mesquita HB, van Duijnhoven FJ, Hallmans G, Weinehall L, Manjer J, Hedblad B, Lund E, Agudo A, Arriola L, Barricarte A, Navarro C, Martinez C, Quiros JR, Key T, Bingham S, Khaw KT, Boffetta P, Jenab M, Ferrari P, Riboli E: General and abdominal adiposity and risk of death in Europe. N Engl J Med 2008;359:2105-2120.

-33 Plachta-Danielzik S, Landsberg B, Johannsen M, Lange D, Müller MJ: Association of different obesity indices with blood pressure and blood lipids in children and adolescents. Br J Nutr 2008;100:208-218.

34 Bosy-Westphal A, Booke CA, Blocker T, Kossel E, Goele K, Later W, Hitze B, Heller M, Gluer CC, Müller MJ: Measurement site for waist circumference affects its accuracy as an index of visceral and abdominal subcutaneous fat in a Caucasian population. J Nutr;140:954-961.

-35 Kaminsky LA, Whaley MH: Differences in estimates of percent body fat using bioelectrical impedance. J Sports Med Phys Fitness 1993;33:172-177.

-36 Vilaca KH, Ferriolli E, Lima NK, Paula FJ, Moriguti JC: Effect of fluid and food intake on the body composition evaluation of elderly persons. J Nutr Health Aging 2009;13:183-186.

37 Mast M, Sönnichsen A, Langnäse K, Labitzke K, Bruse U, Preub U, Müller MJ: Inconsistencies in bioelectrical impedance and anthropometric measurements of fat mass in a field study of prepubertal children. Br J Nutr 2002;87:163-175.

38 Kromeyer-Hauschild K, Dortschy R, Stolzenberg H, Neuhauser H, Rosario AS: Nationally representative waist circumference percentiles in German adolescents aged 11.0-18.0 years. Int J Pediatr Obes 2011; 6:e129-37. 